\title{
Financial Deepening and its Implications on Savings and Investments in Sri Lanka
}

\author{
Dr. W. M. Hemachandra
}

\begin{abstract}
This paper investigates (a) the validity of financial deepening paradigms in the context of Sri Lanka and $(b)$ the effects of financial deepening on savings and investment that promote growth. In investigating financial deepening in Sri Lanka the paper uses three paradigms i.e., Keynesian, McKinnon-Shaw and neo-structuralist. After examining these three versions the paper argues that an improved model which combines both Keynesian and McKinnonShaw versions produces a model more successful in explaining the characteristics of financial deepening in Sri Lanka. The effects of financial deepening on savings and investment were studied using this improved model. Results show that there are several factors other than interest rate influencing financial deepening in Sri Lanka. The study confirms the neo-structuralists' hypothesis which claims that financial deepening has reduced provision of credit to the informal sector. The paper also evaluates the effects of policy changes introduced since 1977 on financial deepening in Sri Lanka.
\end{abstract}

\section{Introduction}

This paper investigates the validity of rival paradigms that claim to explain financial deepening in Sri Lanka during the period 1965.1-1997.4. According to the Kenesian paradigm, financial deepening occurs due to autonomous spending by the government. In the McKinnon-Shaw paradigm, financial deepening occurs with high interest rates, credit expansion and removal or reduction in statutory reserve requirement (SRR). It advocates financial liberalization policies in order to achieve economic objectives, particularly in the developing countries. Neostructuralists argue that in the presence of unorganized money markets (UMM), financial liberalization leads to a reduction in investment, as the credit available in the system declines. This decline in credit is a result of substitution of loans of the UMM for deposits in the organized market. The main objectives of this study are $(i)$ to test these 
three hypotheses in the case of Sri Lanka in order to evaluate the factors that are responsible for financial deepening and (ii) to evaluate the effects of financial deepening on savings and investment in Sri Lanka.

Based on empirical results it can be argued that financial deepening models can be improved by amalgamating Keynesian and McKinnon-Shaw paradigms together. Sri Lankan time series data supports this position.

The financial liberalization policies implemented in $1977^{1}$ have been held responsible for financial deepening in Sri Lanka. In order to test this hypothesis a step dummy is introduced to represent financial liberalization policies of 1977 and thereafter. The value 0 is assigned to the dummy variable for the period prior to 1977.4 and the value 1 is assigned for the period thereafter. The study covers the period 1965.1 to 1997.4 . Time series data are obtained from the Central Bank's publications cited in the article. Quarterly data for the variables for which data were not available were obtained by disaggregating annual data using statistical procedures. ${ }^{2}$ The equations were cast in log form and results are in percentage terms. The reduced form equations were tested using OLS procedures.

\section{Theoretical Background}

Although financial deepening concepts were brought into salience with the seminal work of McKinnon (1973) and Shaw (1973), these ideas can be found in the Keynesian theories. In the Keynesian theory, financial deepening occurs due to an expansion in government expenditure. In order to reach full employment, the government should inject money into the economy by increasing government expenditure. An increase in government expenditure increases aggregate demand and income, thereby raising demand for money. This disequilibrium is resolved by reducing private investments resulting from higher interest rates. Since higher interest rates lower private investment, an increase in government expenditure promotes investments and reduces private investments concurrently (Dornbusch and Fischer 1978, Chap.4).

1/ In 1977 the Sri Lankan economy underwent a series of major policy changes towards economic liberalization including changes in pricing mechanism, interest rate, exchange rates and external trade, and foreign investments. As a result, a number of foreign banks commenced operations in the country and important changes occurred in the financial sector in liberalized atmosphere.

2/ The procedure adopted to obtain 1997 quarterly data was as follows;

1997 1st Quarter $=(3 \times 1996+1 \times 1997) / 16$

2nd Quarter $=(2 \times 1996+2 \times 1996) / 16$

3rd Quarter $=(1 \times 1996+3 \times 1997) / 16$

4 th Quarter $=(1997 \times 4) / 16$

Some other quarterly data were obtained by assuming that growth of those variables has been constant throughout the year. 
McKinnon and Shaw came up with a rival hypothesis that depicts a positive relationship between interest rate and financial deepening. According to them, developing countries have repressed economies with ceilings on interest rates and limitations in credit availability which impose restrictions on growth. Various economists (Fry 1978, Gupta 1984, Lanyi and Saracoglu 1983) have empirically tested the McKinnon-Shaw hypothesis on the positive relationship between interest rates and financial deepening and found mixed results. Kapur (1976) and Matheison (1980) studied constraints on the working capital provided by the banking sector for economic growth. The availability of credit can be taken as the second instrument for financial deepening. Developing countries have been advised to increase the availability of funds by removing restrictions in the financial sector. The third financial deepening instrument that can be identified from the theory is the SRR. A reduction in the reserve ratio or a payment for reserves based on a market clearing loan rate is growth enhancing (Fry 1995).

A group of Neostructuralists (Van Wijnbergen 1982, 1983 and Taylor 1983) demonstrated characteristics that are opposite to the position highlighted by McKinnon and Shaw by analysing the effects on curb markets. ${ }^{3}$ Wijnbergen $(1982,1983)$ concludes that financial liberalization is likely to reduce the rate of economic growth by reducing the total real supply of credit available to investors due to the effects on the curb market. Accordingly, an increase in interest rate will reduce credit available to the informal sector due to substitution of deposits in the organized sector. Further, they stated that reserve requirement in the banking sector may constraint credit supply and that this could not happen in the curb market, which is not subject to reserve requirements. Consequently, the curb market is able to provide more efficient financing. Hence, interest rates, bank credit and reserve requirement can be used to achieve financial deepening.

The relationship between these instruments and financial deepening has been studied empirically by a number of investigators. Atukorala and Rajapathirana (1993) tested the McKinnon-Shaw hypotheses using Sri Lankan time series data on an annual basis for the period 1960-1987 with a dummy variable to represent policy changes in 1977. They confirmed the McKinnonShaw hypothesis that there is a positive relationship between interest rate and financial deepening. However they did not test the time series properties of data such as stationarity and cointegration.

For this paper, the stationarity condition of time series data was examined using unit root tests. According to these tests all series are stationary in their first differences. Therefore, the equations were tested using first differences

3/ This is an unorganized market in which financial transactions take place on an informal basis. 
rather than the level of time series data (Thornton 1994). ${ }^{4}$ Equations were tested using general-to-specific method (known as DHSY procedure (Davidson et al 1978)). Diagnostic tests were conducted using the LaGrange multiplier test of residual serial correlation (LM), Ramsey's, RESET using the square of the fitted values (RESET), Jarque-Bera test for normality of residuals (JB) and White's Heteroscedasticity (W.H.). The test results are indicated under each equation.

While studying the factors responsible for financial deepening and its effects on savings and investment, a combined model representing both Keynesian and Mckinnon-Shaw propositions was evaluated. Model selection criterion was adopted to find out the best model to explain the Sri Lankan case. The best model was selected using J-test ( Davidson and Mackinnon, 1981) and JA-tests (Mizon and Richard, 1986) from the reduced form equations tested on DHSY method. In order to evaluate the models Akaike information criterion and Schwarz Bayesian criterion (Judge et al 1985, pp.245-246) were used. Each time, two types of models i.e. one is with Keynesian hypotheses and the other is on Mckinnon-Shaw hypotheses were also tested.

This study will first test the causes of financial deepening and thereafter test the effects of financial deepening on savings and investment in Sri Lanka using the same techniques.

\section{Financial Deepening in Sri Lanka}

As is evident from the financial deepening indicators there has been financial deepening in Sri Lanka over time. Although there are a number of indicators, which can be used to measure financial deepening, only two indicators are used for estimations in this study.

Table 1 presents some selected statistics to show the nature of financial deepening in Sri Lanka. The share of the financial sector in GDP grew from 0.82 per cent in 1960 to 6.30 per cent in 1997 . Per capita $\mathrm{M}_{3}$ and the ratio of assets of the financial sector to GDP also grew substantially, as shown in the table. The rise of banking density index shows that the number of financial institutions increased, especially in the rural sector. The structure of nominal interest rates has moved up over time, especially with liberalization policies in 1977. According to these indicators there has been financial deepening in the country during the period under review.

4/ Thornton (1994, p.43) has indicated that "If the set of variables are stationary in their first differences (i.e., integrated of order one or I (1) in their terminology) but do not cointegrate, then the only valid relationship that can exist between them is in terms of their first differences. If, however, they do cointegrate, then the modeled relationship should be estimated in levels". 
Table 1

Financial Deepening Indicators for Sri Lanka

\begin{tabular}{|c|c|c|c|c|c|c|c|c|c|}
\hline Indicator & 1960 & 1965 & 1970 & 1977 & 1980 & 1985 & 1990 & 1995 & 1997 \\
\hline $\begin{array}{l}\text { 1. Share of the Financial } \\
\text { Sector in GDP (a) }\end{array}$ & \multicolumn{8}{|c|}{ 1. Share of the Financial } & 6.30 \\
\hline \multicolumn{10}{|l|}{ 2. Real Per Capita } \\
\hline M3 (b) (Rs.) & 204 & 254 & 294 & 788 & 1,338 & 3,949 & 5,775 & 16,544 & 20,699 \\
\hline 3. M3/GDP Ratio & 30.1 & 35.1 & 28.5 & 30.5 & 37.1 & 39.1 & 37.1 & 48.9 & 42.2 \\
\hline \multicolumn{10}{|l|}{$\begin{array}{l}\text { 4. Total assets of the Fin- } \\
\text { ancial Sector (c)/GDP }\end{array}$} \\
\hline Ratio & 43.8 & - & 64.3 & 78.5 & 101.8 & - & 112.5 & 132.5 & 127.6 \\
\hline \multicolumn{10}{|l|}{ 5. Banking Density } \\
\hline Index (d) & 0.0455 & - & 0.1398 & 0.2510 & 0.3587 & 0.4867 & 0.5402 & 0.6636 & 0.7239 \\
\hline \multicolumn{10}{|l|}{ 6. Advances of Commercial } \\
\hline sector/GDP & 8.4 & 9.4 & 11.3 & 16.3 & 25.8 & 23.5 & 25.2 & 27.5 & 24.3 \\
\hline \multicolumn{10}{|c|}{ 7. Private Sector Credit/Total } \\
\hline Domestic Credit & 74.2 & 69.7 & 75.9 & 75.5 & 86.8 & 84.7 & 81.0 & 88.0 & 83.2 \\
\hline \multicolumn{10}{|l|}{ 8. Nominal Interest Rate (e) } \\
\hline$\%$ p.a. & 2.50 & 2.88 & 4.62 & 14.50 & 20.00 & 15.00 & 16.00 & 13.50 & 12.75 \\
\hline
\end{tabular}

$\mathrm{a}=$ At Constant Prices

$\mathrm{b}=\mathrm{M} 1$ plus Time \& Savings Deposits of Commercial Banks and the National Savings Bank

$\mathrm{c}=$ Includes the Central Bank, Commercial Banks, Deposit Taking Institutions and Long-Term Lending Institutions

$\mathrm{d}=$ No. of Bank Branches * 10,000

Mid Year Population

$\mathrm{e}=$ Average of minimum and maximum fixed deposit rates of commercial banks.

1977 has been treated as the turning point in the process of financial deepening. Along with the liberalization policies, key variables such as interest rates, other prices and institutional set up of the financial sector were subjected to transformation. These changes moved up financial deepening indicators, as measured in nominal terms.

\section{Empirical Estimations}

Empirical estimations were carried out to identify factors responsible for financial deepening and the effects of financial deepening on savings and investment. The indicator used to measure financial deepening is the ratio of 
broad money supply to GDP, (M3/Y). Estimations were made based on two models: the McKinnon-Shaw model and an improved model incorporating both McKinnon-Shaw and Keynesian interpretations. This second model is preferred in explaining the Sri Lankan experience with regard to financial deepening. After estimating the causes of financial deepening, the next step is to estimate the effects of financial deepening on savings and investment. In addition to financial deepening there are other factors responsible for the behaviour of savings and investment. The definitions of variables used in the estimations are given in Appendix 1.

\section{A. Causes of financial deepening}

Reduced form equations were estimated to measure the causes of financial deepening. Model 1 represents McKinnon-Shaw paradigm while the Model 2 is an improved model which incorporates the Keynesian paradigm as well. The regression results on the financial deepening indicator are given below.

Model 1- 1 (Eq.1)

$$
\begin{aligned}
& \Delta \ln (\mathrm{M} 3 / \mathrm{Y})_{\mathrm{t}}=0.846 \Delta \ln (\mathrm{M} 3 / \mathrm{Y})_{\mathrm{t}-1}-0.347 \Delta \ln (\mathrm{M} 3 / \mathrm{Y})_{\mathrm{t}-4}+0.346 \Delta \ln (\mathrm{M} 3 / \mathrm{Y})_{\mathrm{t}-5}+ \\
& (-4.41) \\
& 0.070 \Delta \ln \mathrm{d}_{\mathrm{t}-4}-0.429 \Delta \ln \pi_{\mathrm{t}}-0.413 \Delta \ln \text { PERY }_{\mathrm{t}}+0.921 \Delta \ln \text { PERY }_{\mathrm{t}-3} \\
& \text { (2.75) } \\
& (-3.11) \\
& \text { - } 0.862 \Delta \ln \text { PERY }_{\mathrm{t}-4}+0.017 \mathrm{D} 1 \\
& \mathrm{R}^{2}=0.76 \quad \mathrm{D} . \mathrm{W}=1.84 \quad \mathrm{LM}=2.15 * \quad \mathrm{RESET}=0.95 * \quad \mathrm{JB}=3.52 * \quad \mathrm{WH}=0.93 * * * \\
& \text { * The null hypothesis is rejected at } 5 \text { per cent level of significance. } \\
& \text { ** The null hypothesis is rejected at one per cent level of significance. } \\
& \text { *** The null hypothesis is not rejected. } \\
& t \text { statistics are given in parentheses. }
\end{aligned}
$$

The form of the equation is somewhat similar to that of the equation estimated by Atukorala and Rajapathirana (1993). However, the dummy variable identified as positive in their study ${ }^{5}$ is significant in this study too. According to the regression results the nominal interest rate (d) positively

5/ Atukorala and Rajapathirana (1993) have confirmed an existence of positive relationship between dummy variable for policy changes and financial deepening as measured by the indicators of M1 and STD (Savings and Time deposits). 
influenced the financial deepening indicator $\mathrm{M} 3 / \mathrm{Y}$, confirming the McKinnonShaw hypothesis. ${ }^{6}$ Inflation $(\pi)$ has negative effects while real income ( PERY) has mixed effects.

In addition to interest rates there are additional factors ${ }^{7}$ that determine financial deepening in the country. Activities of government (a variable from the Keynesian paradigm), external sector performance and developments in the infrastructural facilities are other factors to be taken into account. While capturing these variables, the following equation was tested on Sri Lankan data.

Modelel 2- - Eq. 2 )

$$
\begin{aligned}
& \Delta \ln (\mathrm{M} 3 / \mathrm{Y})_{\mathrm{t}}=0.776 \Delta \ln (\mathrm{M} 3 / \mathrm{Y})_{\mathrm{t}-1}-0.396 \Delta \ln (\mathrm{M} 3 / \mathrm{Y})_{\mathrm{t}-4}+0.368 \Delta \ln (\mathrm{M} 3 / \mathrm{Y})_{\mathrm{t}-5}+ \\
& \text { (12.93) (-5.03) (4.71) } \\
& 0.082 \Delta \ln \mathrm{d}_{\mathrm{t}-4}-0.382 \Delta \ln \pi_{\mathrm{t}}-0.747 \Delta \ln \text { PERY }_{\mathrm{t}}+ \\
& \text { (3.22) (-2.74) (-4.40) } \\
& 0.008 \Delta \ln \mathrm{DEF} / \mathrm{Y}+0.031 \Delta \ln (\mathrm{RES} / \mathrm{Y})_{\mathrm{t}-1}+0.027 \mathrm{D} 1 \\
& \text { (2.12) } \\
& \text { (2.16) }
\end{aligned}
$$

The variable used for government activities was the budget deficit. ${ }^{8}$ When monetized, the government budget deficit adds to inflation by increasing the money supply. Non- market borrowing, treasury bills and foreign financing have been the major sources of budgetary financing in Sri Lanka. One of the main contributing factors to the budget deficit is increased government

6/ McKinnon-Shaw have used the real interest rate which is covered in this equation by using nominal interest rate along with inflation. Nominal interest rate with inflation rate taken together covers the effect of real interest rate.

7/ Some investigators (King and Levine, 1992) use indices of civil liberties, number of revolutions and number of assassinations in their models that evaluate the growth and financial depth.

8/ Sri Lankan government budget is in a deficit traditionally and the sources of budgetary finance are external sources (foreign loans and grants) and internal sources (market and non-market borrowing). Non market borrowing includes administrative borrowing from major financial institutions and the issuance of treasury bills. The treasury bill limit has been raised from time to time reaching Rs.125,000 million in 1997 from Rs.1,500 million in 1965. Almost the entire amount specified by the limit has been utilized for budgetary finance by 1997 . 
expenditure. ${ }^{9}$ According to the Keynesian version, government expenditure increases the demand for money. Accordingly, the variable used to represent government activities in the equation has rightly shown a positive effect on financial deepening. External reserves have positive and negative effects on the lagged variables in determining $\mathrm{M} 3 / \mathrm{Y}$.

According to Akaike information criterion and Schwarz Bayesian criterion the second specification is favoured. Therefore, the introduction of 'budget deficit' improves the set up of the equation in measuring financial deepening. This confirms that in countries like Sri Lanka, it is not only the prices (interest rates) that matter for financial deepening, but also other factors such as government activities and changes in reserves.

\section{B. Implications of Financial Deepening on Savings and Investments}

\section{(a) Savings}

There is no comon acceptance among economists on the relationship between interest rate and savings. Inconsistency of measurements for savings is one of the factors contributing to this situation. Financial savings in the formal sector do not represent total domestic savings of a country. In Sri Lanka, financial savings (a stock) as could be obtained from monetary statistics represents the savings in the organized financial sector. But the statistics on domestic savings (a flow) has to be collected from the National Accounts. In the literature, there is no common agreement to identify what saving statistics has to be used for estimations. As noted by Arreata (1988, p.593) "Testing the proposition of a positive interest responsiveness of savings as stated by Mckinnon-Shaw models should ideally be based on domestic private savings rather than domestic aggregate savings as the dependent variable. However, the limited domestic private savings data available in LDCs is also subject to serious inaccuracies as gross domestic private savings are generally derived by subtracting government savings from gross domestic savings. In this regard, for instance, Fry (1978) points out that it is possible (though improbable) that Mckinnon's complementarity hypothesis might fare better were a true measure of domestic private savings available”.

In Sri Lanka private savings are estimated in same manner indicated above. The following reduced form equation was tested for private domestic savings in Sri Lanka.

9/ Since the $1980 \mathrm{~s}$, the government had to spend more on defence, public sector rationalization programmes and development activities in the country. Defence expenditure increased due to the civil war while rationalization programmes were initiated to make major changes in the administrative system. Massive development progammes such as the Mahaweli Development Project has also contributed towards the higher expenditures of the government. 
Eq. 3

$$
\begin{aligned}
& \Delta \ln \left(\mathrm{PVS}_{\mathrm{d}} / \mathrm{Y}\right)_{\mathrm{t}}=0.495 \Delta \ln \left(\mathrm{PVS}_{\mathrm{d}} / \mathrm{Y}\right)_{\mathrm{t}-1}-0.051 \Delta \ln (\mathrm{d}-\pi)_{\mathrm{t}-1}-0.079 \Delta \ln (\mathrm{d}-\pi)_{\mathrm{t}-3}+ \\
& (5.57) \quad(2.59) \\
& \left.0.085 \Delta \ln (\mathrm{d}-\pi)_{\mathrm{t}-4}+0.112 \Delta(\mathrm{M} 3 / \mathrm{Y})_{\mathrm{t}-2}-1.748 \Delta \ln (\mathrm{DR})_{\mathrm{t}-5}+0.136 \Delta \ln \mathrm{DEF} / \mathrm{Y}\right)_{\mathrm{t}}- \\
& \text { (3.75) (0.56) (-1.79) } \\
& 0.041 \Delta \ln (\mathrm{DEF} / \mathrm{Y})_{\mathrm{t}-1}+0.048 \Delta \ln (\mathrm{DEF} / \mathrm{Y})_{\mathrm{t}-5}-0.011 \mathrm{D} 1 \\
& (-2.27) \\
& \text { (2.93) } \\
& (-0.72) \\
& \mathrm{R}^{2}=0.58 \quad \mathrm{D} . \mathrm{W}=2.18 \quad \mathrm{LM}=2.98 * * \quad \mathrm{RESET}=2.02 * \quad \mathrm{JB}=5.00 * \quad \mathrm{WH}=2.78 *
\end{aligned}
$$

In the above regression results, financial deepening as measured by $\mathrm{M} 3 / \mathrm{Y}$, is not significant for private savings $\left(\mathrm{PVS}_{\mathrm{d}}\right)$. As predicted by McKinnonShaw the real interest rate $(\mathrm{d}-\pi)$ is significant. Private savings have been determined by various factors other than financial deepening. Lagged values of private savings,${ }^{10}$ dependency ratio (DR) and government saving ratio $(\mathrm{DEF} / \mathrm{Y})(=$ budget deficit/Y) are the other factors affecting private savings. DR has a negative effect on private savings confirming, a priori, expectations that a higher dependency ratio reduces savings. There is a highly significant effect from government budgetary activities. According to regression results, initially, higher the government deficit, higher the private savings. Since private savings are derived by subtracting government savings from domestic savings, private savings are higher than domestic savings because of negative savings of the government. Later, since the government has to borrow from domestic sources to fill the budget deficit, private savings are converted into investments in the public sector. Therefore, private savings will decline with budget deficit. For instance, the major savings institutions in the private sector such as the Employees' Provident Fund and the National Savings Bank invest their savings in government paper such as treasury bills and bonds. This leads to a reduction in private savings. The negative coefficient on lagged variable of $D E F / Y$ in the regression confirms this proposition.

Real income and economic growth were not significant in the estimations. The policy variable too was not significant.

The following reduced form equation was tested for domestic savings. Real interest rate $(\mathrm{d}-\pi)$ and financial deepening $(\mathrm{M} 3 / \mathrm{Y})$ are not significant in this specification. However, the bank branch expansion (BBR),${ }^{11}$ dependency

10/The lag value of savings on domestic saving function has been found to be significant in studies (see Mapalad (1998).

11/As Fry (1995, p.164) estimated, an increase in branch proximity is responsible for raising national savings ratio. Further, as Lewis (1955) claims that "Experiences show that the amount of savings depends partly on how widespread these facilities (i.e., savings institutions) are; if they are pushed right under the individual's nose ... people save more than if the nearest institution is some distance away". 
ratio (DR) and government savings to domestic savings ratio (DEF/Sd) are significant. Financial deepening indicator (M3/Y) has an insignificant effect on domestic savings. Accordingly, there are other factors, in addition to financial deepening, that determine domestic savings in the country.

$\underline{\text { Eq. }} . \underline{4}$

$$
\begin{aligned}
& \Delta \ln \left(\mathrm{S}_{\mathrm{d}} / \mathrm{Y}\right)_{\mathrm{t}}=0.714 \Delta \ln \left(\mathrm{S}_{\mathrm{d}} / \mathrm{Y}\right)_{\mathrm{t}-1}-0.139 \Delta \ln \left(\mathrm{S}_{\mathrm{d}} / \mathrm{Y}\right)_{\mathrm{t}-4}+0.024 \Delta \ln (\mathrm{d}-\pi)_{\mathrm{t}-5}+ \\
& \text { (11.92) (-2.31) (1.46) } \\
& 0.054 \Delta \ln (\mathrm{M} 3 / \mathrm{Y})_{\mathrm{t}-1}-2.704 \Delta \ln \mathrm{DR}_{\mathrm{t}-5}+0.034 \Delta \ln \left(\mathrm{DEF} / \mathrm{S}_{\mathrm{d}}\right)_{\mathrm{t}-4}- \\
& (0.31) \quad(-3.27) \\
& 0.002 \Delta \mathrm{BBR}_{\mathrm{t}}+0.002 \Delta \mathrm{BBR}_{\mathrm{t}-1}-0.016 \mathrm{D} 1 \\
& (-2.21) \quad(2.80) \quad(-1.10) \\
& \mathrm{R}^{2}=0.67 \quad \mathrm{D} . \mathrm{W}=1.88 \quad \mathrm{LM}=0.57 * \quad \mathrm{RESET}=0.04 * \quad \mathrm{JB}=225.24 * \mathrm{WH}=0.005 * * *
\end{aligned}
$$

Domestic savings include savings from the organized as well as unorganized sectors. Financial deepening has affected the activities in the organized sector significantly while in the unorganized sector, its influence is insignificant. The following equation on savings in the organized sector shows the positive effects from financial deepening and real interest rate. Though the real interest rate in above estimation is insignificant, the real interest rate is positive and significant for organized sector savings (in Eq 5), which are the savings included in the measurements of $\mathrm{M} 3 / \mathrm{Y}$. The factors responsible for the organized sector saving ratio as measured by total deposits in the banking system to GDP ratio (DEPO/Y) are shown in the Eq.5. In the equation, DEPO represents demand deposits plus time and saving deposits.

\section{$\underline{\text { Eq. }}$.}

$$
\begin{aligned}
& \Delta \ln \mathrm{DEPO} / \mathrm{Y}_{\mathrm{t}}=0.721 \Delta \ln \mathrm{DEPO} / \mathrm{Y}_{\mathrm{t}-1}-0.178 \Delta \ln \mathrm{DEPO} / \mathrm{Y}_{\mathrm{t}-3}+0.362 \Delta \ln \mathrm{DEPO} / \mathrm{Y}_{\mathrm{t}-4}+ \\
& \text { (12.30) } \\
& (-4.96) \\
& 0.009 \Delta \ln \mathrm{d}-\pi-1.920 \Delta \ln \mathrm{DEPY}_{\mathrm{t}-3}+2.007 \Delta \ln \text { PERY }_{\mathrm{t}-4}+ \\
& \text { (2.35) (-9.83) (11.05) } \\
& 0.039 \Delta \ln (\mathrm{RES} / \mathrm{Y})_{\mathrm{t}-1}+0.992 \Delta \ln (\mathrm{M} 3 / \mathrm{Y})_{\mathrm{t}}-0.756 \Delta \ln (\mathrm{M} 3 / \mathrm{Y})_{\mathrm{t}-1}-0.006 \mathrm{D} 1 \\
& \text { (2.14) } \\
& \text { (2.28) } \\
& \text { (0.84) } \\
& \mathrm{R}^{2}=0.93 \text { D. } \mathrm{W}=1.91 \quad \mathrm{LM}=2.02 * \quad \mathrm{RESET}=1.02 * \mathrm{JB}=1.83 * \mathrm{WH}=6.68 *
\end{aligned}
$$


Financial deepening has highly significant positive and negative effects on organized sector savings. McKinnon-Shaw hypotheses on positive effects from financial deepening and real interest rate on savings is valid for savings in the organized sector in Sri Lanka. However, the interest rate is not the only factor that determines savings in the organized sector. Other factors include the changes in real income and external reserves. In selecting a model for savings in Sri Lanka, the influence of the other factors has to be considered.

\section{(b) Investments}

Investment is crucial for economic growth. In the estimations this is measured by the investment output ratio (I/Y). According to Keynesian interpretation real interest rate has positive as well as negative effect on investments. The positive impact comes from increased income due to higher government expenditure. The increase in aggregate demand increases interest rates as well as investment in the government sector. These positive as well as negative influences of interest rate on investment can be interpreted from the dynamics in investment function (Eq.6). Eq.6 includes government activities too. Government activities (DEF/Y) have a positive impact on investment while at the same time, they have a negative impact on private investments arising from interest rates. This model includes both Mckinnon-Shaw and Keynesian interpretations with regard to private investment. The MckinnonShaw school assumes a positive relationship between real interest rates and private investment. The following reduced form equation produces the regression results on this relationship with other variables that are significant.

\section{Eq.6}

$$
\begin{aligned}
& \Delta \ln (\mathrm{PTI} / \mathrm{Y})_{\mathrm{t}}=0.980 \Delta \ln (\mathrm{PTI} / \mathrm{Y})_{\mathrm{t}-1}-0.167 \Delta \ln (\mathrm{PTI} / \mathrm{Y})_{\mathrm{t}-4}-0.006 \Delta \ln (\mathrm{d}-\pi)_{\mathrm{t}-2}+ \\
& \text { (23.52) } \\
& (-4.50) \\
& (-2.00) \\
& 0.007 \Delta \ln (\mathrm{d}-\pi)_{\mathrm{t}-4}+0.004 \Delta \ln \mathrm{DEF} / \mathrm{Y}-0.015 \Delta \ln (\mathrm{DCP} / \mathrm{DC})_{\mathrm{t}-4}+ \\
& (-0.40) \\
& 0.171 \Delta \ln (\mathrm{DCP} / \mathrm{DC})_{\mathrm{t}-4}-0.158 \Delta \ln (\mathrm{DCP} / \mathrm{DC})_{\mathrm{t}-5}-0.158 \Delta(\mathrm{FDI} / \mathrm{Y})_{\mathrm{t}}+ \\
& 0.002 \Delta(\mathrm{AID} / \mathrm{Y})_{\mathrm{t}}+0.076 \Delta(\mathrm{COM})_{\mathrm{t}}-0.137 \Delta(\mathrm{COM})_{\mathrm{t}-1}+0.062 \Delta(\mathrm{COM})_{\mathrm{t}-2}+ \\
& 0.083 \Delta \ln (\mathrm{M} 3 / \mathrm{Y})_{\mathrm{t}}-0.152 \Delta \ln (\mathrm{M} 3 / \mathrm{Y})_{\mathrm{t}-1}+0.106 \Delta \ln (\mathrm{M} 3 / \mathrm{Y})_{\mathrm{t}-2} \\
& \mathrm{R}^{2}=0.88 \quad \text { D. } \mathrm{W}=1.57 \quad \mathrm{LM}=3.43 * * \quad \mathrm{RESET}=0.71 * \quad \mathrm{JB}=31.42 * \quad \mathrm{WH}=0.41 * * *
\end{aligned}
$$


Hence, the ratio of domestic credit to private sector in domestic credit (DCP/DC) and the real interest rate (d- $\pi$ ) are influential in determining private investment. Private investment (PVTI/Y) in Sri Lanka cannot be explained alone by the behaviour of real interest rates. There are numerous other factors affecting the investment ratio. Among these, there are foreign direct investments (FDI/Y), foreign aid (AID/Y) and communications developments $(\mathrm{COM})$ which have influenced the private investment behaviour. These other factors are significant in explaining the Sri Lankan private investment behaviour as is the real interest rate. Financial deepening indicator (M3/Y) has positive as well as negative influences on private sector investments. Therefore, unlike in the private savings function, financial deepening has an effect on private investments. Financial deepening has encouraged the private investment. The reason is that most investment originates from the facilities extended by the formal sector such as bank credit. Since these are widely affected by financial deepening activities, private investment that originates from them are also sensitive to the behaviour of interest rates and financial development.

Real interest rate has a positive impact on the total domestic investment function too. Other factors that affect the investment ratio (I/Y) are the private sector credit ratio (DCP/DC), foreign direct investments (FDI/Y), foreign aid (AID/Y), government activities (DEF/Y) and financial deepening. Some dynamics are shown in the negative and positive values of the variables. The dummy and the constant term are not significant in this specification either. Total investment estimated in National Accounts include not only private investment but also the government and other public enterprises, which have a link to interest rates. Impact of the interest rate in the total domestic investment is also positive. The following regression results show the factors that explain the behaviour of domestic investment ratio of the country.

\section{Eq.7}

$$
\begin{aligned}
& \Delta \ln (\mathrm{I} / \mathrm{Y})_{\mathrm{t}}=0.956 \Delta \ln (\mathrm{I} / \mathrm{Y})_{\mathrm{t}-1}-0.668 \Delta \ln (\mathrm{I} / \mathrm{Y})_{\mathrm{t}-4}+0.513 \Delta \ln (\mathrm{I} / \mathrm{Y})_{\mathrm{t}-5}+ \\
& \text { (23.69) } \\
& (-11.31) \\
& \text { (9.09) } \\
& 0.020 \Delta \ln (\mathrm{d}-\pi)_{\mathrm{t}-5}+0.205 \Delta \ln (\mathrm{DCP} / \mathrm{DC})_{\mathrm{t}-1}+0.010 \Delta(\mathrm{FDI} / \mathrm{Y})_{\mathrm{t}-4}+ \\
& 0.005 \Delta \ln (\mathrm{AID} / \mathrm{Y})+0.234 \Delta \ln \mathrm{COMLA} / \mathrm{Y}-0.217 \Delta \ln (\mathrm{COMLA} / \mathrm{Y})_{\mathrm{t}-1}+ \\
& 0.202 \Delta \ln (\mathrm{COMLA} / \mathrm{Y})_{\mathrm{t}-3}+0.011 \Delta \ln (\mathrm{DEF} / \mathrm{Y})_{\mathrm{t}-1}-0.006(\mathrm{DEF} / \mathrm{Y})_{\mathrm{t}-2}- \\
& 0.220 \Delta \ln (\mathrm{M} 3 / \mathrm{Y})_{\mathrm{t}-1}+0.187 \Delta \ln (\mathrm{M} 3 / \mathrm{Y})_{\mathrm{t}-2} \\
& (-2.49) \\
& \mathrm{R}^{2}=0.91 \quad \mathrm{D} . \mathrm{W}=1.54 \quad \mathrm{LM}=3.35 * * \quad \mathrm{RESET}=1.62 * \quad \mathrm{JB}=0.02 * * \quad \mathrm{WH}=0.06 * * *
\end{aligned}
$$


Accordingly, the government's budgetary activities, loans from commercial banks, foreign direct investments and foreign aid significantly influence the domestic investment.

According to above analysis, there is an extensive influence from the activities of the informal sector on savings and investment behaviour in the country. This helps to confirm the Neostructuralists' hypotheses about the unorganized market. During the period covered in the study, development programmes initiated by government have largely contributed to transform the rural sector to handle its activities in a more organized manner. With rural development programmes, the rural sector was provided with banking facilities among other things, which led to increase the monetization of this sector. This has been confirmed by the highly significant variable for bank branch expansion (BBR) in the equation for domestic savings (Eq.4). As these branches were established mainly in the rural sector, financial deepening has led to attracting deposits from the informal sector to the formal or organized sector. An equation was tested to see whether there has been a reduction in credit provided in the unorganized sector due to financial deepening. Although there is no complete set of data relating to financial activities of the unorganized sector, a variable was selected to represent the credit availability in the unorganized sector. This is the ratio of credit from the commercial banks to agricultural sector/GDP (AGLN/Y). As evident from Eq.8 financial deepening has negatively affected credit to the agricultural sector. The equation tested for the period $1977.4-1997.4$ is as follows.

\section{Eq. 8}

$$
\begin{aligned}
& \Delta(\mathrm{AGLN} / \mathrm{Y})_{\mathrm{t}}=0.798 \Delta(\mathrm{AGLNI} / \mathrm{Y})_{\mathrm{t}-1}-0.500 \Delta(\mathrm{AGLN} / \mathrm{Y})_{\mathrm{t}-4}+0.426 \Delta(\mathrm{AGLN} / \mathrm{Y})_{\mathrm{t}-5}- \\
& 0.122 \Delta(\mathrm{d})_{\mathrm{t}-4}+0.079 \Delta(\pi)_{\mathrm{t}-1}+0.051 \Delta(\mathrm{DEF} / \mathrm{Y})_{\mathrm{t}-3}-0.042 \Delta(\mathrm{M} 3 / \mathrm{Y})_{\mathrm{t}-3}
\end{aligned}
$$

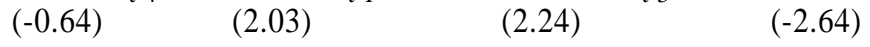

$$
\begin{aligned}
& \mathrm{R}^{2}=0.70 \quad \mathrm{D} . \mathrm{W}=2.01 \quad \mathrm{LM}=1.99 * \quad \mathrm{RESET}=1.09 * \quad \mathrm{JB}=1.90 * \quad \mathrm{WH}=0.02 * * *
\end{aligned}
$$

The financial deepening indicator (M3/Y) has a highly significant negative coefficient confirming that financial deepening reduces credit to the informal sector. There is no effect from interest rate. Notably, government activities measured by $\mathrm{DEF} / \mathrm{Y}$ have a positive effect on credit availability to the informal sector. 


\section{Conclusions and Policy Implications}

In the study, the financial deepening was studied using two types of rival models i.e., Mckinnon-Shaw and Keynesian.

According to these results, it is not only the interest rate that affects financial deepening in Sri Lanka but also, various other factors such as government activities, external sector activities, and bank branch expansion and communications development. The test results of the study showed that there is a positive relationship between these variables and financial deepening indicators and that of savings and investment in Sri Lanka.

The Mckinnon-Shaw hypothesis on the positive relationship between the reduction of SRR and financial deepening is rejected in the light of the regression results. However, the influence of availability of credit for financial deepening and for investment has been confirmed by the positive results in the regressions. Improvements in the availability of highly interest sensitive credit to the private sector from the banking sector during the period under study in Sri Lanka have been the main causal factor for this. In the savings function, the interest rate is not significant due to many factors other than interest rates affecting savings in the country. However, the positive interest rate-saving relationship can be observed for savings in the organized sector, in particular. Although financial deepening has influenced savings in the organized sector, it has not influenced domestic savings, which includes government savings as well.

In the equations that were tested for causes of financial deepening the dummy variable was significant. Therefore, it has to be concluded that policy changes in 1977 made some contribution to financial deepening. However, this hypothesis has to be rejected in the case of savings and investment behaviour.

As hypothesized by Neostructuralists, it is confirmed that financial deepening has acted negatively in providing credit to the informal sector. This may be because government paid more attention to develop the industrial and service sectors than to the informal sector. During the last three decades Sri Lanka has been providing extensive credit facilities to industrial and services sectors. Further, commercial banks are more willing to provide credit to organized sector since there is a lower credit risk associated with such lending when compared to the informal sector.

From this study, it can be concluded that policies relating to the financial sector should be persuade on a continuous basis rather than responses to short term developments in the monetary sector. The insignificant dummy variable in the savings and investment functions proposes that the policy changes have not resulted on savings and investment. 
The transformation of the rural sector into a more organized sector involving banking activities has improved banking habits among the people and helped to reduce the dependency on informal markets for financial needs. This transformation has helped reduce high interest costs of borrowing in the informal sector.

It indicates that government activities still play a predominant role in the financial sector although the reforms relating to privatization are in progress. A more developed financial sector can be expected from high-level private sector development. The government sector too can be benefited from a developed financial sector since it could be used to satisfy government's financial needs. This does not mean that the concentration on the real sector should be reduced. Real sector development should be undertaken hand in hand with financial sector development for sustained growth, which is the ultimate objective of the financial sector developments. 


\section{Appendix 1}

Variables used in the study are as defined below.

AGLN/Y = Commercial banks' loans for agricultural purposes/GDP ratio

$\mathrm{AID} / \mathrm{Y}=$ Foreign aid to GDP ratio

$\mathrm{BBR}=$ No of bank branches

$\mathrm{COM}=$ Proxy for communication developments (No of telephones)

COMLA/Y $=$ Commercial banks loans and advances to GDP ratio

$\mathrm{d}=$ Nominal interest rate for savings deposits of commercial banks

$\mathrm{DCP} / \mathrm{DC}=$ Domestic credit to private sector/Total domestic Credit ratio

$\mathrm{DEF} / \mathrm{S}_{\mathrm{d}}=$ Government deficit to domestic savings Ratio

$\mathrm{DEF} / \mathrm{Y}=$ Government deficit to GDP ratio

$\mathrm{DEPO} / \mathrm{Y}=$ Total deposits of banking sector to GDP ratio

$\mathrm{DR}=$ Dependency Ratio

D1 = Dummy variable to measure policy changes in 1977

(The value 0 was assigned for the period prior to 1977.4 and the value 1 was assigned for the period thereafter)

$\mathrm{FDI} / \mathrm{Y}=$ Foreign direct investments to GDP ratio

$\mathrm{M} 3 / \mathrm{Y}=$ Broad money supply to GDP ratio

$\pi=$ Inflation Rate

PERY = Per capita real income

$\mathrm{PTI} / \mathrm{Y}=$ Private investments to GDP ratio

PVTS $_{\mathrm{d}} / \mathrm{Y}=$ Private domestic savings to GDP ratio

$\mathrm{RES} / \mathrm{Y}=$ External reserves to GDP ratio

$\mathrm{S}_{\mathrm{d}} / \mathrm{Y}=$ Domestic savings to GDP ratio

$\mathrm{SRR}=$ Statutory reserve requirement ratio

$\mathrm{Y}=\mathrm{GDP}$ at current prices 


\section{References}

Atukorala P. and Rajapatirana S., 1993, Liberalization of the Domestic Financial Market; Theoritical Issues with Evidence from Sri Lanka, International Economic Journal, 7 (4, Winter), pp. 17-33.

Central Bank of Sri Lanka, 1998, Economic Progress of Independent Sri Lanka.

Central Bank of Sri Lanka, Annual Reports (Different Issues).

Central Bank of Sri Lanka, Bulletins (Different Issues).

Central Bank of Sri Lanka, Consumer Finances and Socio Economic Survey Reports, Part (i) and Part (ii), Different Volumes.

Davidson J.H., Hendry D.H., Srba F. and Yeo S., 1978, Econometric Modeling of the Aggregate Time-Series Relationship between Consumers' Expenditure and Income in the United Kingdom, The Economic Journal, 88 pp. 661-692.

Davidson R. and Mackinonn J.G., 1981, Several Tests for Model Specification in the presence of Alternative Hypotheses, Econometrica, 49, pp.781-793.

Dornbush R. and Fischer S., 1978, Macro Economics, Mcgraw-Hill Book Company.

Gupta K.L., 1984, Finance and Economic Growth in Developing Countries, London: Croom Helm.

Fry M.J., 1978, Money and Capital or Financial Deepening in Economic Development?, Journal of Money, Credit and Banking, 10 (4, November), pp. 464-475.

Fry M.J., 1995, Money, Interest and Banking in Economic Development, (2nd edition) The Johns Hopkins University Press.

Judge G.G., Griffiths W.E., Hill R.C., Lutkepohl H. and Lee T.C., 1985, The Theory and Practice of Econometrics, 2nd edition, J.Willey \& Sons, INC, New York.

Kapur B.K., 1976, Alternative Stabilization Policies for Less Developed Countries, Journal of Political Economy, 84 (4, August), pp. 777-795.

King R. and Levine R., 1992, Financial Indicators and Growth in Cross Section of Countries, Policy Research Working Papers No. 819, Washington , D.C., World Bank. 
Lanyi A. and Saracoglu R., 1983 b, The Importance of Interest Rates in Developing Economies, Finance and Development, Vol. 20, No. 2 (June).

Mapalad M.C.M., 1998, Foreign Capital Inflow and Domestic Savings in the Philippines, Savings and Development, No.1, xxii.

Mathieson D.J., 1980, Financial Reforms and Stabilization Policy in a Developing Economy, Journal of Development Economics, 7 (3 September), pp. 359-395.

Mckinnon Ronald I., 1973, Money and Capital in Economic Development, Brooking Institute.

Mizon G.E. and Richard J.F., 1986, The Encompassing Principle and its Application to Testing Non-Nested hypotheses, Econometrica 54, pp.657678

Shaw Edward S., 1973, Financial Deepening in Economic Development, Oxford University Press.

Taylor L., 1983, Structuralist Macro Economics: Applicable Models for the Third World, New York : Basic Books.

Thornton J., 1994, Financial Deepening and Economic Growth: Evidence from Asian Economies, Savings and Development, No. 1, xviii.

Van Wijnbergen S., 1982, Stagflationary Effect of Monetary Stabilization Policies: A Quantitative Analysis of South Korea, Journal of Development Economics, 10 (2, April), pp. 133-169. 